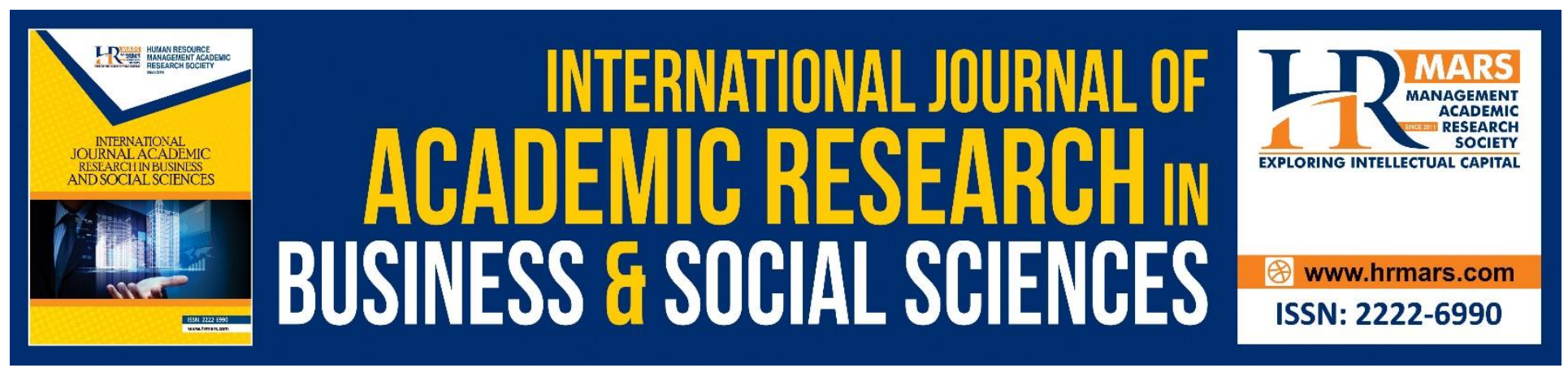

\title{
Exploring the Legal and Safety Issues amongst Event Planners and Venue Managers in Malaysia
}

Masrur Mohd Khir, Nur Atiqah Rochin Demong, Nor Lela Ahmad, Sarinah Sabar, Emi Normalina Omar

To Link this Article: http://dx.doi.org/10.6007/IJARBSS/v9-i3/5709

DOI: $\quad 10.6007 /$ IJARBSS/v9-i3/5709

Received: 21 Feb 2019, Revised: 26 March 2019, Accepted: 06 April 2019

Published Online: 13 April 2019

In-Text Citation: (Khir, Demong, Ahmad, Sabar, \& Omar, 2019)

To Cite this Article: Khir, M. M., Demong, N. A. R., Ahmad, N. L., Sabar, S., \& Omar, E. N. (2019). Exploring the Legal and Safety Issues amongst Event Planners and Venue Managers in Malaysia. International Journal of Academic Research in Business and Social Sciences, 9(3), 499-511.

\section{Copyright: (C) 2019 The Author(s)}

Published by Human Resource Management Academic Research Society (www.hrmars.com)

This article is published under the Creative Commons Attribution (CC BY 4.0) license. Anyone may reproduce, distribute, translate and create derivative works of this article (for both commercial and non-commercial purposes), subject to full attribution to the original publication and authors. The full terms of this license may be seen

at: $\underline{\text { http://creativecommons.org/licences/by/4.0/legalcode }}$

Vol. 9, No. 3, 2019, Pg. 499 - 511

http://hrmars.com/index.php/pages/detail/IJARBSS

JOURNAL HOMEPAGE

Full Terms \& Conditions of access and use can be found at http://hrmars.com/index.php/pages/detail/publication-ethics 


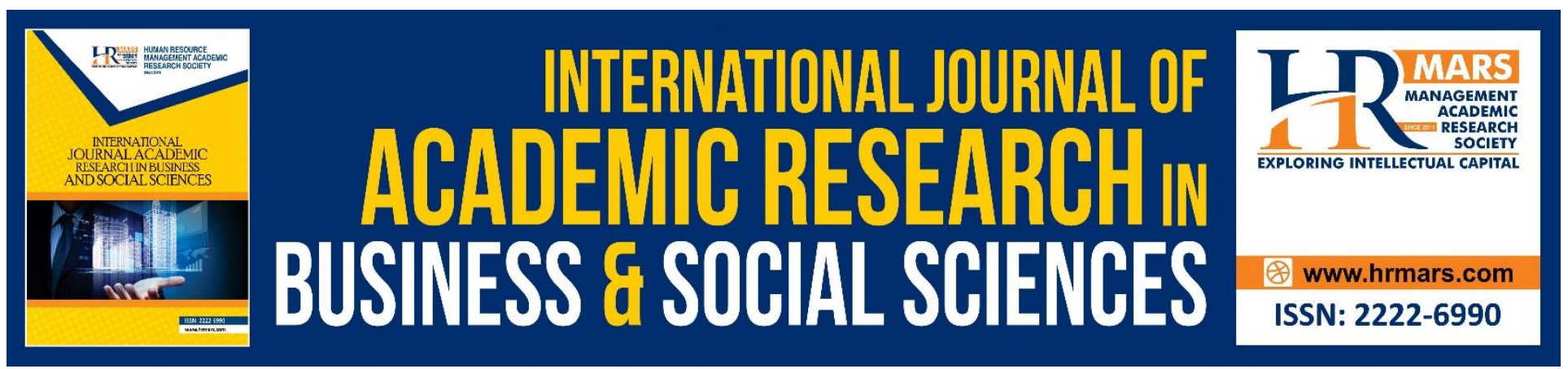

\title{
Exploring the Legal and Safety Issues amongst Event Planners and Venue Managers in Malaysia
}

\section{Masrur Mohd Khir ${ }^{1}$, Nur Atiqah Rochin Demong ${ }^{2}$, Nor Lela Ahmad ${ }^{3}$ Sarinah Sabar ${ }^{4}$, Emi Normalina Omar ${ }^{5}$}

${ }^{1}$ Universiti Teknologi MARA, Center for Postgraduate and Professional Studies, Faculty of Business and Management, 40450 Shah Alam, Selangor, Malaysia

2 Universiti Teknologi MARA, Faculty of Business and Management, 42300 Puncak Alam, Selangor, Malaysia

${ }^{3}$ Universiti Teknologi MARA, Center for Postgraduate and Professional Studies, Faculty of Business and Management, 40450 Shah Alam, Selangor, Malaysia

${ }^{4}$ Universiti Teknologi MARA, Center for Management and Administrative Studies, Faculty of Business and Management, 42300 Puncak Alam, Selangor, Malaysia

${ }^{5}$ Universiti Teknologi MARA, Center for Technology and Supply Chain Management Studies, Faculty of Business and Management, 42300 Puncak Alam, Selangor, Malaysia

\begin{abstract}
Event planners and venue managers were ultimately held responsible for improper standards of control in any events that they are responsible with. The implementation of risk and safety procedures within the event site will not always preclude the defendant from legal liability. This paper explored the significance of legal and safety issues among event planners and venue managers in Malaysian event management industry. Despite a plethora of literature confirming that legal and safety issues are fundamental in event risk management, a thorough literature review has exposed the insufficiency of research of these intertwine areas. This empirical investigation has been taken in order to investigate the perceptions of event planners and venue managers in Malaysia towards legal and safety issues in planning and managing events. Due to the lack of empirical studies in this area, a qualitative exploratory case study approach using semi-structured interviews has been conducted aiming at exploring the importance of this topic, and to identify (and justify) several important legal acts (Law of Malaysia) within the event management context. The sample participants were recruited based on purposive sampling technique comprising of six event planners and three venue managers from various event related organisations in Malaysia. The data were analysed inductively using constant comparison method. The findings identify three major organisations responsible for the implementation and enforcement of legal and safety issues as well
\end{abstract}


INTERNATIONAL JOURNAL OF ACADEMIC RESEARCH IN BUSINESS AND SOCIAL SCIENCES

Vol. 9, No. 3, March, 2019, E-ISSN: 2222-6990 @ 2019 HRMARS

as eight Malaysian legal acts which regulates the event management industry namely the Occupational Safety and Health Act 1994 (Act 514), Factories and Machinery Act 1967 (Act 139), Environmental Quality Act 1974 (Act 127), Explosives Act 1957 (Act 207), Peaceful Assembly Act 2012 (Act 736), Fire Services Act 1988 (Act 341), Employees' Social Security Act 1969 (Act 4) and Civil Aviation Act 1969 (Act 3).

Keywords: Perceptions, Risk, Planning, Managing

\section{Introduction}

The Event Management Body of Knowledge (EMBOK) outlined risk management as one of the five important pillars of this multi-disciplinary field (Silvers, 2005). Thus, when discussing risk, one has to discuss legislation or the legal aspects as these two aspects are very much interrelated, as according to MacLaurin and MacLaurin (2001), failure to mitigate risk can expose the meeting and event planners to undesirable legal and negligence liabilities. Eisenhauer (2005) highlighted legal compliance as key risk category for all event organizers in which any case of non-compliance may result in risk litigation, fines and sanctions. As such, Gaynor (2009) insisted that part of ensuring due diligence for the risk and safety aspect in planning and organizing events is getting the lawyers (or those responsible for legal matters) to agree with planning concepts early in the planning process. However, event managers need to be aware of the fact that "different laws and standards apply for different events especially regarding the location (venue or outdoors) and therefore they comply with different authorities" (Eisenhauer, 2005). Based on this context, this article identified that the main legislation that governed the safety and health aspects of employees in Malaysia is the Occupational Safety and Health Act 1994 - Act 514. This act provides the legislative framework to secure the safety, health and welfare among the Malaysian workforce and to protect others against risks to safety or health in connection with the activities of persons at work (Laws of Malaysia - Act 514) (Legal Research Board, 2007). This Occupational Safety and Health Act 1994 (Act 514) was approved by the Parliament in 1993 and was gazette on February 1994 (Legal Research Board, 1990). All organizations in the country regardless of government or private sectors are subjected to the jurisdiction of the act, and this includes the event management industry as well. In the event management context, this act in particular requires the event planners and venue managers to assess all risks involved and implement controls to minimize those risks. Thus, all event planners and venue managers are responsible for the health and safety of all stakeholders involved in event projects such as the events' audiences, contractors, suppliers, volunteers, participants, and so on. The formation of this act has enhanced the establishment of several other organizations pertinent to the health and safety regulations in the country. In terms of the general risk management and safety practices, the Malaysian government has established the Department of Occupational Safety and Health and the National Institute of Safety and Health, both under the umbrella of Ministry of Human Resource (Johnny, Yapat, \& Janius, 2013). Both of these agencies were responsible to protect and safeguard the health and safety practice across all sectors and industries including the event management industry.

The Employee's Social Security Act 1969 (Act 4) is another act which was also established to further safeguard and protect all employees in Malaysia (Ahmad, 1999). The government has established the Social Security Organization (SOCSO) in 1971 under the Human Resources Ministry to 
implement and administer the social security schemes under the Employee's Social Security Act 1969 (Act 4) which regulates the Employment Injury Insurance Scheme and the Invalidity Pension Scheme. Under this scheme, workers are protected against industrial accident including accident occurred while working, occupational diseases, invalidity or death due to any cause (Laws of Malaysia - Act 4) (Department of Occupational Safety and Health, 2010). According to this act, it is compulsory that all employers and employees of public and private organizations including event management organizations to contribute a certain amount from their remuneration as compensation in any unwanted accidents that happened at workplace. To further enhance this aspect, the government has launched the National Institute of Occupational Safety and Health (NIOSH) in an effort to promote the occupational safety and health and to also serve as the backbone in creating a self-regulating occupational safety and health culture in Malaysia (National Institute of Safety and Health, 2013). The function of this safety organization in Malaysia is quite similar to the Institution of Occupational Safety and Health (IOSH) in UK which act as a chartered body for health and safety professionals (The Institution of Occupational Safety and Health, 2010) and the National Institute for Occupational Safety and Health (NIOSH) USA which is a federal agency responsible for conducting research and making recommendations for the prevention of work-related injury and illness (National Institute of Safety and Health, 2010). Hence, these two acts (Act 514 and Act 4) are critical to uphold the safety and health aspects of event stakeholders based on Eisenhauer's (2005) views that occupational health and safety was a major legal compliance for all event organizers. But in Malaysia, the question remains on the implementation and enforcement within the service industry, particularly in this emerging leisure and event management sector.

Apart from these two major acts, the event management organizations in Malaysia were also governed by other relevant acts (wherever applicable) such as Factories and Machinery Act 1967 (Revised 1974 - Act 139), Fire Services Act 1988 (Act 341) and Food Act 1983 (Act 281), as the legislation pertaining to food safety is so significant to the event industry. The principal food law in Malaysia is the Food Act 1983 and the Food Regulations 1985, which are developed and amended by the Food Safety and Quality Division (FSQD) of the Malaysian Ministry of Health (Malaysia Food Act 1983 (Act 281) and Food Regulations 1985 (Legal Research Board, 1990). According to Mellor and Veno (2002), most of the legal liabilities that event planners and venue managers might be subjected to can be transferred through insurance. "An insurance policy is a contract that establishes a binding legal relationship that is regulated by both the common law and the legislation" (Eisenheur, 2005). Arcodia and McKinnon (2005) also particularly mentioned the importance of public liability insurance for the event management industry. But Callander and Page (2003) warned that even if an event planner or a venue manager takes a precaution of having insurance to cover public liability, complete with extensions including punitive and exemplary damages, their duties to the insurer must be met as failure to take sufficient risk and safety precautions could potentially place them at risk of having the claim refused. However, the compliance to the requirements of insurances and specific legislations do not signify that the safety issues will not escalate in the country's event and leisure industries. Hence, this paper carries an importantly significant objective to ascertain the level of awareness among Malaysian event planners and venue managers towards the Malaysian acts, as the law is of course useless unless it is seen to be enforced. 


\section{Methodology}

It has been argued that qualitative methods played a significant role in British leisure research from its beginning in the 1970s (Veal, 2006). Hence, the nature of leisure research was more suitable for qualitative methods according to the opinion of Kraus and Allen (1998) who stated that: "in such an individualistic and diversified field as recreation and leisure, there ought to be a place for research of a more deeply probing, intuitive, or philosophical nature". Thus, this paper undertook a qualitative approach with event planners and venue managers from various types of Malaysian event related organizations. Qualitative data are generally expressed in the form of words and provide a means for developing a deeper understanding of a particular phenomenon within a specific context (Mallen and Adams, 2008). Creswell (2009) interprets qualitative frameworks as "an inquiry process of understanding a social or human problem, based on building a complex, holistic picture, formed with words, reporting detailed views of informants, and conducted in a natural setting".

These exploratory interviews with event planners and venue managers were important to gather the primary data based on the respondents' experience in the industry particularly on their awareness to legal and safety issues as well as to investigate the views and perceptions from the industry point of view. Sampling for this qualitative study was purposive and sought to achieve maximum variation in relation to types of event related organizations represented by the informants. The researcher was required to actively select the most productive sample to answer the research question and this strategy was based on the researcher's practical knowledge of the research area and the available literature and evidence from the study itself.

In this context, the researcher carried out semi-structured interviews with a total of nine respondents. To be precise, four respondents were from private event management companies, while another two were from government event management agencies and three informants were actually recruited from among event venue providers.

The interview scripts were analyzed using constant comparison methods. This method was originally developed for use in grounded theory methodology, however it is now applied more widely as a method of analysis in qualitative research (Janesick, 1994; Strauss and Corbin, 1990). It requires the researcher to take one piece of data (one interview or one theme) and compare it to all other pieces of data that are either similar or different. This method of analysis is inductive as the researcher begins to examine data critically and draw new meaning from the data (Dye, Schatz, Rosenberg, and Coleman, 2000).

\section{Results and Discussion}

It would incomplete for any topic related to the event risk management and safety to not be accompanied by the legislation and litigation aspect. According to Abbott and Geddie (2001), failure to mitigate risk can expose event planners as well as venue managers to undesirable legal and negligence liabilities. Therefore, apart from the findings from informants, this part also will briefly discuss the existing legislation situation for the event management industry in Malaysia. It will start by describing the roles of several governmental safety and health organizations that were responsible for the issues of risk and safety in Malaysia. The differences between the roles that these organizations played were also highlighted. After that this paper will look into some of the Malaysian 
legal acts that were deemed to be relevant to the event industry and have been mentioned by the participants.

In general, there are three different organizations that are responsible for the risk, safety and health issues within Malaysian legal framework across all sectors and industry including the tourism and event management fields. These organizations were fully owned by the government of Malaysia and administered by the Ministry of Human Resources. But they each have different objectives and different roles to play in terms of safety and health purposes

The first is the Department of Occupational Safety and Health (DOSH) which is responsible for ensuring the safety, health and the welfare of people at work as well as protecting other people from the safety and health hazards arising from the activities of all different sectors in Malaysia ranging from manufacturing and construction to the services industry such as the tourism and event management area (Department of Occupational Safety and Health, 2013). In other words, the establishment of DOSH has the mission to ensure that all private and public companies provide a safe and healthy work environment for all their employees and also to protect other who may be affected by their activities (Johnny et al, 2013). As a government agency, the department is responsible for the administration and enforcement of legislation related to the occupational safety and health of the country. This department actually had the mission to become an organization that can lead the nation in creating a safe and healthy work culture that contributes towards enhancing the quality of working condition (Department of Occupational Safety and Health, 2010). Among the most important objectives by DOSH to the event management industry was pertaining to their role of ensuring that all event management organizations comply with all requirements of legislation related to safety and health as stated in the Occupational Safety and Health Act 1994 (Act 514), as well as regulation and codes of practice which have been approved within the industry. Unfortunately, it was the enforcement role of this agency that has been questioned by quite a significant number of respondents:

"Because this (act) 514 is not only for the construction, covers all occupations other than two that are the army and navy, they don't use that." (P1)

"So, we can see a very lacking of the monitoring and enforcement aspects for the theatres and event industry. Nowadays government is going mostly to the construction sector, the construction industry got some government enforcement as the safety risk due to the higher risks involve actually compared to the theatres."

On the other hand, the National Institute of Safety and Health (NIOSH) which was part of the Centers for Disease Control and Prevention (CDC) was put under the jurisdiction of the Department of Health and Human Services, had a slightly different role with regards to the safety and health practice in the country (National Institute of Safety and Health, 2013). This federal agency is responsible for conducting research and making recommendations for the prevention of workrelated injury across all sectors and industries including event management. The main purpose of this institute is to generate new knowledge in the field of occupational safety and health, and later transfer that knowledge into practice for the betterment of workers within all industries in Malaysia. 
The Social Security Organization (SOCSO) which was formed in 1971 under the Ministry of Human Resources also an agency responsible for managing issues related to the risk, safety and health. SOCSO was originally established to provide social security protections to all employees/workers in Malaysia. This organization has been set up by the government to administer, enforce and implement the 'Employees' Social security Act 1969' and the 'Employees Social security (General) Regulation 1971.' These acts acted like a general insurance cover since it stated that employers with a monthly income of MYR 3000 (Malaysian Ringgit) or below, along with their employees were required to make contributions. Any event/venue managers and employees who are registered under the SOCSO will be provided with social security protection by social insurance which includes medical, cash benefits, provision of artificial aids and rehabilitation to employees to reduce the sufferings. As been noted, the event management industry was clearly exposed to numerous types of risk and safety hazards, therefore, the contribution to this agency would help to minimize the impact that may be suffered by those involved in safety incidents and/or accidents.

Although all of these agencies' existence was for the common purpose of the betterment of risk, safety and health practice in the country there were explicit differences in the roles played by them. DOSH main task was to provide a safe and healthy working environment for all employees and to protect others who may be affected by its activities. NIOSH on the other hand was responsible for conducting research and making recommendations for the prevention of work-related injury and illness, whereas SOCSO was in charge of providing social security protection through the social insurance for all employees in the country including those from the event management industry.

Legislation and the Event Industry: Abbott and Geddie (2001) highlighted some legal case analyses for event managers and planners to obtain a valuable understanding of the necessity for crowd control and the preventive measures they can utilise in preparing for an event. Although these cases were specifically for crowd safety and focused on US law and court cases, it is nonetheless the case that event planners and venue managers could gain meaningful insights regarding what action or inaction is considered reasonable with respect to crowd control and management. Taking inspiration from their work, this paper would also highlight certain legislation that seemed to be important for the Malaysian event management industry. Although there is still no standard procedure in this area, some respondents did mention certain facets of the Law of Malaysia (Malaysian Act) that were relevant to the event management domain, and some had already implemented it in their event operations. For example, there were a few participants who mentioned the relevance of occupational safety and health law that was related to the Occupational Safety and Health Act 1994 (Act 514).

".... All other works must use [Act 514], the act binds all including sweeping floors, staging and theatres, singers and everything, all legally binds by this act!" (P4)

The discussion of legislation among the informants was sufficiently explored within the event management framework based on the objective of this paper that is to explore the awareness of the legal and safety aspects within this particular domain. However, there were some limitations as this paper would not be able to provide any legal cases in a Malaysian scenario as it has not explored any of such cases, unlike what have been done by Abbott and Geddie (2001) for their study on legislation 
of crowd control and crowd management in the US. Thus, the purpose of this paper was only to create awareness of some Malaysian acts that were important for this industry based on the participants' perceptions. This was based on the notion that an effective planning system for safety and health requires an organization to establish and to operate a safety and health management system which controls risk (Health and Safety Executive, 2003). Hence, this article illustrates certain legislations that were pertinent to the event management industry perceived by participants in this investigation (Table 1). But another thorough investigation is maybe needed on the practicality and whether such legislation could be implemented in the event management industry in Malaysia.

Table 1: Certain legislations that were pertinent to the event management industry perceived by participants in the investigation

\begin{tabular}{|c|c|c|}
\hline $\begin{array}{l}\text { Law of } \\
\text { Malaysia } \\
\text { (Malaysian } \\
\text { Act) }\end{array}$ & $\begin{array}{l}\text { Risk / Safety } \\
\text { area }\end{array}$ & Response (excerpt from respondents) \\
\hline $\begin{array}{l}\text { Occupational } \\
\text { Safety and } \\
\text { Health Act } \\
1994 \text { (Act } \\
514 \text { ) }\end{array}$ & $\begin{array}{l}\text { Crowd Safety } \\
\text { and crowd } \\
\text { control }\end{array}$ & $\begin{array}{l}\text { "First of all I would have to refer to the act. My act is I am } \\
\text { registered with the DOSH, } 514 \text { year } 1994 \text {. The act has } \\
\text { been gazette at the parliament for some reasons. First, to } \\
\text { make sure of the safety and health for all workers. } \\
\text { Secondly to protect all workers in that working place. } \\
\text { Thirdly to encourage the safe environment for all } \\
\text { employees. And then to implement ways or procedures } \\
\text { according to the law. These were all its purposes, I would } \\
\text { have to follow this." (P1) } \\
\text { "Occupational safety and health, yeah... [...] This is where } \\
\text { we comes in as provider which we have to more or less go } \\
\text { according to their requirements, which OSHA would } \\
\text { normally come inspect the property for about twice in a } \\
\text { year. They come and inspect in terms of our safety, how } \\
\text { often do we practice our safety committee meetings, how } \\
\text { often do we practice our safety drill, how often we } \\
\text { servicing our smoke detectors, how often do we service } \\
\text { our alarm systems, so these are been done accordingly } \\
\text { twice a year. So, we more or less we obliged to their } \\
\text { requirements and we go according to the required." (P7) }\end{array}$ \\
\hline $\begin{array}{l}\text { Factories and } \\
\text { Machinery }\end{array}$ & $\begin{array}{l}\text { Technical } \\
\text { and logistics }\end{array}$ & $\begin{array}{l}\text { "We comply almost all whatever requirements. For } \\
\text { example, how do you say, I give you an example for } \\
\text { scaffolding... Oh! FMA, another one is FMA. Factory and }\end{array}$ \\
\hline
\end{tabular}




\begin{tabular}{|c|c|c|}
\hline $\begin{array}{l}\text { Act } 1967 \text { (Act } \\
139)\end{array}$ & & $\begin{array}{l}\text { machinery act. [...] Basically for example are, in FMA they } \\
\text { also mention about scaffolding, and in OSHA also they } \\
\text { also mention about scaffolding. So, whatever scaffolding } \\
\text { is been erected in the center whatsoever, we would try to } \\
\text { comply with whatever the legal requirement. For } \\
\text { example, scaffolding erected more than } 2 \text { meters we } \\
\text { would require a P endorsement, and then the erecter } \\
\text { must be a competent person. So those are the } \\
\text { requirement that we comply." (P1) } \\
\text { "Yes, we have act 5... the factories and machinery act } \\
\text { 1967, that one involved machinery in which we have at } \\
\text { the back there sky jet upright and also overhead crane, } \\
\text { that involves the PMA, permit 'mesin angkat' (licensing } \\
\text { for heavy machineries). So, that one has to be renewed } \\
\text { annually and required DOSH to come and do the } \\
\text { inspection." (P5) }\end{array}$ \\
\hline $\begin{array}{l}\text { Environment } \\
\text { al Quality Act } \\
1974 \text { (Act } \\
127 \text { ) }\end{array}$ & $\begin{array}{l}\text { Environment } \\
\text { al safety and } \\
\text { health }\end{array}$ & $\begin{array}{l}\text { "Yes, we do! In fact we have the list, we have the legal } \\
\text { register. In our management system we have the legal } \\
\text { register which we identify all the legal requirement that } \\
\text { we have to comply in Malaysia. For example, OSA, OSHA, } \\
\text { then we have to comply with BB, building by law, and } \\
\text { then Fire act, EQA environment quality act, there is a few I } \\
\text { can't really remember all..." (P3) }\end{array}$ \\
\hline $\begin{array}{l}\text { Explosives } \\
\text { Act } 1957 \text { (Act } \\
207 \text { ) }\end{array}$ & $\begin{array}{l}\text { Technical } \\
\text { and logistics } \\
\text { (risk of fire) }\end{array}$ & $\begin{array}{l}\text { "Yes, the district police, they have their own protocol. } \\
\text { Any application you apply to district police, district police } \\
\text { will send to the arms and explosives department to look } \\
\text { into what you are going to fire and all that, you have a } \\
\text { supporting letter, and then they send to the Police } \\
\text { headquarters, because only the State Chief of Police is } \\
\text { authorized, he is the licensing officer. [...] He is the } \\
\text { licensing officer... that comes under the Explosive Act } \\
\text { 1957 if I'm not mistaken. I think Explosive Act } 1957 . . . " \\
\text { (P4) } \\
\text { ".....pyrotechnics is like a special requirement. Do you } \\
\text { know that pyrotechnics require license? So, most of the } \\
\text { event organizers they are not aware of all these, so we } \\
\text { are here to advise them...[...]But we have to ensure that } \\
\text { they comply, whatever legal requirement, regulations } \\
\text { that is applicable to events, we have to ensure that these }\end{array}$ \\
\hline
\end{tabular}


INTERNATIONAL JOURNAL OF ACADEMIC RESEARCH IN BUSINESS AND SOCIAL SCIENCES Vol. 9, No. 3, March, 2019, E-ISSN: 222 2-6990 @ 2019 HRMARS

\begin{tabular}{|c|c|c|}
\hline & & $\begin{array}{l}\text { organizers, or event organizers or contractors comply } \\
\text { with it." (P6) }\end{array}$ \\
\hline $\begin{array}{l}\text { Peaceful } \\
\text { Assembly Act } \\
2012 \text { (Act } \\
736 \text { ) }\end{array}$ & $\begin{array}{l}\text { Crowd Safety } \\
\text { and crowd } \\
\text { control }\end{array}$ & $\begin{array}{l}\text { "Number two is on the ground is the same as any events, } \\
\text { we have to have the permits from the police because you } \\
\text { are gathering more than twenty people, you have to get a } \\
\text { permit from the police. And of course permission from } \\
\text { the local government like council, we have to inform } \\
\text { them. Normally we get them involved in our } \\
\text { committee."(P8) }\end{array}$ \\
\hline $\begin{array}{l}\text { Fire Services } \\
\text { Act } 1988 \text { (Act } \\
341)\end{array}$ & $\begin{array}{l}\text { Technical } \\
\text { and logistics } \\
\text { (fire and } \\
\text { electrical } \\
\text { hazards) }\end{array}$ & $\begin{array}{l}\text { "We have 'Bomba' act (Fire act) that involves fire but that } \\
\text { one also been put under [the jurisdiction of] act } 514 \text { also." } \\
\text { (P1) }\end{array}$ \\
\hline $\begin{array}{l}\text { Employees' } \\
\text { Social } \\
\text { Security Act } \\
1969 \text { (Act 4) }\end{array}$ & $\begin{array}{l}\text { Crowd Safety } \\
\text { and crowd } \\
\text { control }\end{array}$ & $\begin{array}{l}\text { "All our employees have SOCSO, all have it. [...] SOCSO is } \\
\text { compulsory for the management, right? As somebody } \\
\text { who is sensitive to the workers I will be responsible for } \\
\text { those who is under me..." (P2) }\end{array}$ \\
\hline $\begin{array}{l}\text { Civil Aviation } \\
\text { Act } 1969 \text { (Act } \\
\text { 3) }\end{array}$ & $\begin{array}{l}\text { Technical } \\
\text { (aviation } \\
\text { events and } \\
\text { fireworks) }\end{array}$ & $\begin{array}{l}\text { "Well, basically in Malaysia the event itself, in event, } \\
\text { aviation events, it has been regularized by the } \\
\text { Department of Civil Aviation. So, these are the things that } \\
\text { you have to take heed to what are the requirements, the } \\
\text { requirements of the.... well, it will regulates, it will cover } \\
\text { almost all aspects of the event itself. So, we have to pay } \\
\text { insurances, the licenses... Of course number one is if you } \\
\text { don't have permission from DCA you cannot do it, it's } \\
\text { against the law. [...] DCA, for the air you have to abide } \\
\text { their law which is the priority number one." (P9) } \\
\text { "Wait, wait... Simultaneously when you apply you also } \\
\text { have to apply for DCA (Department of Civil Aviation) for } \\
\text { fireworks, Department of Aviation. Anything above } 500 \\
\text { feet you must get DCA approval, and you also have to } \\
\text { apply for 'Bomba' (fire department) [...] } 50 \text { metres or } 500 \\
\text { feet I forgot, and you have to also have the Bomba (fire } \\
\text { department approval). 'Bomba' you need to have for } \\
\text { fireworks, for pyro-technics..." (P4) }\end{array}$ \\
\hline
\end{tabular}




\section{Conclusion}

This article provided succinct discussions in terms of the legislation aspects related to the event planning and management. The focus was primarily on current state of the implementation and enforcements of Malaysian acts within the event management industry particularly from risk and safety perspectives. There are three governmental agencies responsible for the implementation, management and enforcement of health and safety across all sectors (including leisure and events) namely the Department of Occupational Safety and Health (DOSH), National Institute of Safety and Health (NIOSH) and Social Security Organization (SOCSO), the latter specifically tasked with compensation and insurance matters resulting from work-related injuries. There were also discussions on the country's legal acts (Law of Malaysia) relevant to the event management industry as perceived by the participants of this study, such as: Occupational Safety and Health Act 1994 (Act 514); Factories and Machinery Act 1967 (Act 139); Environmental Quality Act 1974 (Act 127); Explosives Act 1957 (Act 207); Peaceful Assembly Act 2012 (Act 736); Fire Services Act 1988 (Act 341); Civil Aviation Act 1969 (Act 3); and Employees' Social Security Act 1969 (Act 4). The implementation and enforcement of these acts within the event management sector might enhance the risk and safety best practices. But more importantly, this study has provided an empirical findings on the identification and awareness of relevant legislation acts by events' planners and venue managers that was liable within the event management discipline. These acts were actually important regulations and legal requirements pertaining to the event risk and safety practices in Malaysia. It is also expected that by exploring the significance of all these legislation acts, the event and venue managers will be able to obtain a valuable understanding of the necessity for the management of risk and safety preventive measures in order to avoid any sort of legal implications and liabilities that may arise.

\section{Acknowledgement}

The authors would like to acknowledge Faculty of Business and Management for funding the study. We also acknowledge the event planners and venue managers for their willingness to provide the necessary information.

\section{Corresponding Author}

Masrur Mohd Khir, Faculty of Business and Management, Malaysia, masrur@uitm.edu.my, Universiti Teknologi Mara, 40450, Shah Alam.

\section{References}

Abbott, J., \& Geddie, M.W. (2001). Event and venue management: Minimizing liability through effective crowd management techniques. Event Management, 6(4), 259-270

Ahmad, S. (1999). Malaysian legal system. Kuala Lumpur, Malaysia: Malayan Law Journal Sdn. Bhd.

Arcodia, C., \& McKinnon, S. (2005). Public liability insurance: Its impact on Australian rural festivals. Journal of Convention \& Event Tourism, 6, 101-110

Callander, M., \& Page, S.J. (2003). Managing risk in adventure tourism operations in New Zealand: a review of the legal case history and potential for litigation. Tourism Management, 24(1), 1323 
INTERNATIONAL JOURNAL OF ACADEMIC RESEARCH IN BUSINESS AND SOCIAL SCIENCES

Vol. 9, No. 3, March, 2019, E-ISSN: 222 2-6990 @ 2019 HRMARS

Creswell J. W. (2009). Research design: Qualitative, Quantitative and Mixed Method Approaches (3rd ed.). Los Angeles, California: Sage.

Department of Occupational Safety and Health, (2010). The role and development. Department of Occupational Safety Health. Retrieved from http://www.dosh.gov.my/index.php?option=com_content\&view=article\&id=84:the-roleand-development\&catid=39:dosh-profile\&Itemid=750\&lang=en

Department of Occupational Safety and Health, (2013). Introduction: Department of Occupational Safety and Health. Retrieved from http://www.dosh.gov.my/index.php?option=com_content\&view=article\&id=78:introductio n\&catid $=39$ \& Itemid $=750$ \&lang $=e n$

Dye, J. F., Schatz, I.M., Rosenberg, B.A., \& Coleman, S.T. (2000). Constant Comparison Method: A Kaleidoscope of Data. The Qualitative Report, 4(1), 1-10. Retrieved from http://nsuworks.nova.edu/tqr/vol4/iss1/8

Eisenhauer, S. (2005). Sports events and risk management in New Zealand: How safe is safe enough? Masters Thesis, University of Otago, Dunedin.

Gaynor, P. T. (2009). Special event planning for the emergency manager. Journal of Business Continuity \& Emergency Planning, 4(1), 14-21

Health \& Safety Executive, (2003). An introduction to health and safety. Sudbury, England: HSE Books. Janesick, V. J. (1994). The dance of qualitative research design: Metaphor, methodology, and meaning. In N. K. Denzin \& Y. S. Lincoln (Eds.), Handbook of qualitative research (pp. 209-219). Thousand Oaks, CA: Sage.

Johnny, J. G., Yapat, J.A., \& Janius, N. (2013). The differences role of safety and health organization in Malaysia. Retrieved from http://www.slideshare.net/joyCgrace/aw101-the-differences-roleof-safety-and-health-organization-in-malaysia

Kraus, R. G., \& Allen, L. (1998). Research \& evaluation in recreation, parks \& leisure studies (2nd ed.). Boston, United States: Allyn \& Bacon.

Legal Research Board, (1990). International Law Book Services Legal Research Board: Food Act, 1983 (Act 281) \& Food Regulations, 1985: As at 15th December 1990. Kuala Lumpur, Malaysia: International Law Book Services.

Legal Research Board, (2007). Occupational safety and health act 1994 (act 514) and regulations and orders. Petaling Jaya, Malaysia: International Law Book Services.

MacLaurin, T. L. and D. J. MacLaurin, 2001. Convention Planning Essentials: The critical role of food safety. Journal of Convention \& Exhibition Management, 2(4), pp. 3-22.

Mallen, C. \& Adams L. J. (2008). Sport, recreation and tourism event management: theoretical and practical dimensions. Oxford, England: Butterworth-Heinemann.

Mellor, N., \& Veno, A. (2002). Planning safe public events: practical guidelines. Canberra, South Africa: Attorney General's Department.

National Institute of Occupational Safety and Health, (2010). The Institution of Occupational Safety and Health. Retrieved from http://www.iosh.co.uk/about_us/who_we_are.aspx

National Institute of Occupational Safety and Health, (2013). NCSB (NIOSH Certification Sdn. Bhd.) Background. National Institute of Occupational Safety and Health. Retrieved from 
INTERNATIONAL JOURNAL OF ACADEMIC RESEARCH IN BUSINESS AND SOCIAL SCIENCES

Vol. 9, No. 3, March, 2019, E-ISSN: 222 2-6990 @ 2019 HRMARS

http://www.ncsb.com.my/index.php?option=com_content\&view=article\&id=378\&ltemid=2 5

Silvers, J. R. (2005). The potential of the EMBOK as a risk management framework for events. Paper presented at the 2005 Las Vegas International Hospitality and Convention Summit, University of Nevada, Las Vegas.

Strauss, A., \& Corbin, J. (1990). Basics of qualitative research: Grounded theory procedures and techniques. Newbury Park, CA: Sage.

Veal, A. J. (2006). Research methods for leisure and tourism: A practical guide. Edinburgh, Scotland: Pearson Education. 